\title{
Undisciplined Reviewed From the Habitus Pierre Bourdieu Theory
}

\author{
Mustofa $^{1^{*}}$ \\ ${ }^{1}$ Department of Education and Human Potentials Development \\ Hua-Shih College of Education, National Dong Hwa University, Hualien, \\ Taiwan Republic of China \\ 1No. 1號, Section 2, Daxue Road, Shoufeng Township, Hualien County, Taiwan 974 \\ Email: 810888111@gms.ndhu.edu.tw
}

\begin{abstract}
The background undisiciplined attitude of students is found in daily life such as being late to class, littering, breaking traffic and other undisciplined attitudes. Though discipline is an important factor that determines success in the future. This study aims to uncover and explore the underlying causes of undisciplined attitudes in student life. Then explain and provide solutions to get used to the discipline in life. This study focuses on undisciplined attitudes that occur among students of the Nahdlatul Ulama University of Surabaya by determining the sample. This research uses descriptive survey method. The sample was taken from the representation of students in each faculty totaling 6 Faculties so that the data obtained varied. The average sample is 25 students from each faculty. The results showed that all students who were given the questionnaire were undisciplined in their daily lives. In conclusion Undisciplined attitude due to environmental influences (objectivism) and low self-awareness (subjectivism), which is in harmony with Pierre Bourdieu's habitus theory.
\end{abstract}

Keywords:undisciplined, student, unusa, habitus, bourdieu 


\begin{abstract}
Abstrak
Latar belakang penelitian ini yaitu sikap siswa yang tidak terduga ditemukan dalam kehidupan sehari-hari seperti terlambat ke kelas, membuang sampah sembarangan, melanggar lalu lintas dan sikap tidak disiplin lainnya. Padahal disiplin adalah faktor penting yang menentukan kesuksesan di masa depan. Penelitian ini bertujuan untuk mengungkap dan mengeksplorasi penyebab yang mendasari sikap tidak disiplin dalam kehidupan siswa. Kemudian menjelaskan dan memberikan solusi untuk membiasakan diri dengan disiplin dalam kehidupan. Penelitian ini berfokus pada sikap tidak disiplin yang terjadi di kalangan mahasiswa Universitas Nahdlatul Ulama Surabaya sebagai sampel. Penelitian ini menggunakan metode survei deskriptif. Sampel diambil dari representasi mahasiswa di setiap fakultas yang berjumlah 6 Fakultas sehingga data yang diperoleh bervariasi. Sampel rata-rata adalah 25 siswa dari masing-masing fakultas. Hasil penelitian menunjukkan bahwa semua siswa yang diberi kuesioner tidak disiplin dalam kehidupan sehari-hari mereka. Kesimpulannya sikap tidak disiplin karena pengaruh lingkungan (objektivisme) dan rendahnya kesadaran diri (subjektivisme), yang selaras dengan teori habitus Pierre Bourdieu.
\end{abstract}

Kata Kunci: tidak disiplin, pelajar, unusa, habitus, bourdieu 


\section{INTRODUCTION}

It is an underestimation to say that proper discipline leads to great achievements and for that matter student who are disciplined tend to do well academically(Gyan 2015). But among students the problem of undisciplined still often found, especially among students of the Nahdlatul Ulama Surabaya. The problem of undisciplined in Indonesia is actually a classic problem, but it is always actual and crucial to study because until now there has been no solution and no change.

Previous research only focused on finding quantitative facts about undisciplined attitudes. There is no research that tries to explore in-depth why students are not disciplined and then provide recommendations for solutions so that discipline in everyday life. Research does that. Students become subjects because they are an important national entity that will determine the progress of a nation in the future.

Discipline is an important part of increasing the progress of the nation. Discipline is of great importance in every walk of our life. Without it, we cannot prosper in this world. Students as the next generation of the nation have a very strategic position. Therefore students must have the high discipline to be able to realize an advanced and civilized life. The University Nahdlatul Ulama of Surabaya (Unusa) has a tag line "Printing the Lil Rahmatal Rahmatal Generation", so to realize the tag line the discipline of Unusa students has a very important role.

This research was conducted at the Nahdlatul Ulama University of Surabaya. Based on observations of many students who have not behaved in disciplines such as being late to college and littering. Discipline has not become a habit in the daily life of students.

Discipline wastes time and automatically delays everything that should have happened. These problems occur every day so that everyday losses occur. Not only loss in time but also have an impact on material losses. When we refer to the Edward Norton Lorenz Butterfly effect theory "dependence is sensitive to initial conditions" where small changes in a place in a non-linear system can result in large differences in later conditions. This means that discipline greatly impacts the social, cultural, and economic life of the community unnoticed. That is one of the reasons for the slow development of Indonesia, which is so different from Singapore, China, even Thailand, as Suryo Pratomo has reviewed in his article (Media Indonesia, 20/12/2017).

Undisciplined is a habit that is repeated, the attitudes that occur under the conscious. Simply put, undisciplined is a habit of attitudes that are embedded for a long time and even lasts from generation to generation so that it has become a habit that is 
called by Pierre Bourdieu as Habitus. Habitus is a historical product formed after humans were born and interacted with society at a certain time and space. Habitus is not natural, it is not natural nature that complements humans, both psychologically and biologically. Habitus is the result of learning through parenting, play activities, and also community activities in the broadest sense. The learning takes place smoothly, unconsciously and appears as a natural thing, so as if something natural is as if given by nature or already from there (Takwin 2009).

Undisciplined Is HabitusDiscipline in terms of sociology, discipline consists of two parts, namely self-discipline and social discipline. Both are related to each other so that someone who has a disciplined attitude is people who can direct their attitudes and actions based on certain standards or limits of behavior that are accepted in the group or social sphere.

Some behaviors can have a negative impact on the self-esteem of the students especially when a student disrupts class by consistently going to class late or when a student talks while the teacher is teaching or writes graffiti on school property. Furthermore, another student may be shouting in class or asking questions already answered or defy the teacher's instructions and walk around in the class or just become destructive(Mokaya J. Omote 2015).

(Macquarrie 2016) explains in terms of ethics, namely, discipline is a willingness and actions of someone in complying with all the rules that are more stringent with specific goals. This means that discipline is an important attitude in everyday life as a social creature.

Discipline according to Hodges (Helmi 1996) is the attitude of a person or group who intends to follow the rules that have been set. Humans as individual creatures according to Durkheim do not have autonomy in themselves in acting. Since being born into the world he has been introduced to the existing order, then there is a process of socialization until the individual does something according to the rules of community propriety. This is what distinguishes Bourdieu from Durkheim. Bourdieu places the individual as a subject in the sense that he has also autonomy in him. Discipline is the attitude of someone who is not completely resigned to the circumstances but the individual has autonomy for himself. The term Bourdieu is objectivism and subjectivism. Both have a reciprocal relationship, that is what is called by Bourdieu with habitus. Furthermore, the 
habitus concept is very valuable in exploring the interconnectedness of structural relationships and individual characteristics (McLaughlin 2015).

Bourdieu explains that habitus is: "understood as a system of lasting transposable dispositions which, integrating past experiences, functions at every moment as a matrix of perceptions, appreciations, action and makes possible the achievement of infinitely diversified tasks (Rob Warwick, Janet McCray 2017). Therefore Habitus is a generative process of habit and repetition, but not one that implies an automatic reflex. Instead, it is a condition of practice that shortcuts the numerous options available to the novice to a narrower range of reasonable contextual possibilities. Later he stresses in The Logic of Practice that habitus is: 'embodied history, internalized as second nature and so forgotten to history - it is an active presence of the whole of which it is the product (Rob Warwick, Janet McCray 2017).

According to Bordieu individuals are not merely social products that are not able to provide personal rebuttal or consideration of social influence as an objective structure. Individuals have an important role to change for the better. Undisciplined that has not become a habit of society can still be changed into part of everyday attitudes even though it takes a long time. The process of getting used to the discipline by means of planting from childhood begins with the family environment. This is included in the category of selfdiscipline, according to Jasin (in Helmi 1996) discipline that is developed or controlled by himself.

Objectivism is emphasizing the role of structures that determine actors and their social environment by looking at the macro. Whereas subjectivism emphasizes the actions of actors in their analysis, namely views from the micro side. Undisciplined is a social process that is influenced by the environment but human beings as individual beings actually have autonomy in themselves.

A Discipline that comes from self-awareness is a manifestation and actualization of personal responsibility. It means recognizing and accepting values that exist outside of him. This is a process of learning (socialization) from family and community. The cultivation of the values of discipline, which is instilled by parents, teachers, and the environment is a positive provision for the growth and development of self-discipline. Instilling the values of self-discipline can be floating if it is supported by a conducive environmental situation that is characterized by the consistent treatment of parents, teachers, and their environment(Helmi 1996). 
According to set and achieve goals requires consistent self-discipline. If not disciplined and consistent in daily life the results sought will be sporadic and difficult to understand. This means that discipline really determines one's success, so it is not surprising that developed countries start from the very high discipline of their people.

There is no peace in the home without discipline, even a small family will not be happy without discipline. A home without discipline is like a wild forest, not a lovely garden. The family is an example of a small organization in which there are leaders and management in achieving the goals of a happy life. if the State is likened to a family. The purpose of the country is to make the people prosperous so they can live happily. Welfare can be obtained if the country and the nation are pro-active in realizing it. The state together with the community must be disciplined in daily life. Obey rules, rules, which have been set.

(Richard 2007) argues that if fighting without discipline is the same as fighting crime. Richard's opinion is not excessive considering that undisciplined is a source of chaos and commotion. Watch and feel when on the highway chaos due to undisciplined drivers makes everyone stressed. The delay of the seminar for being undisciplined wastes a lot of time and adds more and more work. Students late to class disrupt the focus and concentration of their classmates. Undisciplined must be stopped by revealing the cause first and then finding solutions as recommendations.

Undisciplined has become a habit of life. These habits are referred to by Pierre Bourdieu as habitus. Habitus is a cognitive structure that mediates between individuals and social reality. Individuals use habitus in dealing with social reality(Takwin 2009). Entering classes late, attending forums late, breaking traffic signs, littering, and all other activities are daily habits. In this social space, individuals with their habitus relate to other individuals and various social realities that produce actions according to their realm and capital.

The difference between this research and previous research is that this research shows the collected data will be explained with a philosophical approach using Pierre Bourdieu's habitus theory. Undisciplined is a daily habit that has become a habit. This habit is carried out without "realizing" that it is not disciplined wrong but because it has become common to almost all people do so as there is a disposition from the community. In fact, there are people who reject and feel disadvantaged by the undisciplined which happens every day. 
Undisciplined is an attitude that has become a habit. This habit is indeed difficult to change because it is internalized even though the individual still has autonomy in himself. This habit has been going on for a long time from childhood to adulthood formed in space and time (the community) which undisciplined.

\section{METHODS}

This research uses descriptive survey method. This method is carried out to measure certain social phenomena, then explained descriptively or narratively. Researchers do a direct exploration of the experience that is realized by the culprit and illustrate the meaning in it. The research location at the University Nahdlatul Ulama of Surabaya, using purposive sampling subjects determined by representatives of each faculty. The study participants numbered 150 students from six faculties (the Faculty of Nursing and Midwifery, the Faculty of Health, the Faculty of Medical, the Faculty of Business Economics, Faculty of Teacher Training and Education, and the Faculty of Engineering). To find out quantitative facts, researchers used a questionnaire to find out the daily attitude of the discipline. After completing the questionnaire to confirm and explore the undisciplined habits of the participants were interviewed in-depth (dept interview).

Figure 1

Components of Data Analysis Miles \& Huberman

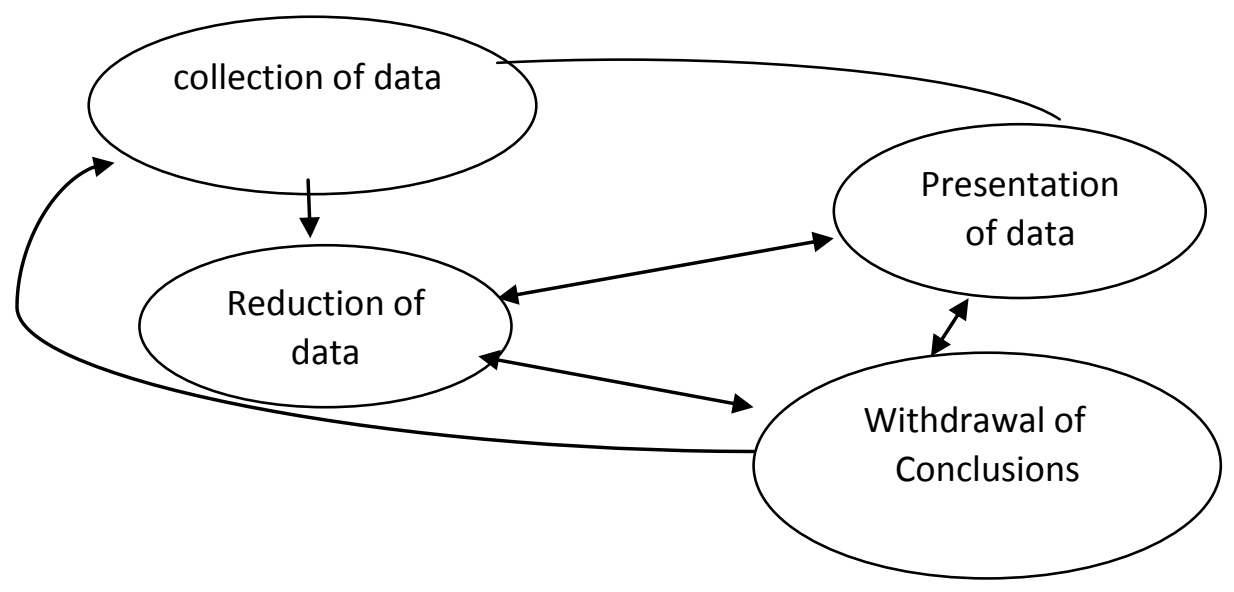

Source from Sugiyono, 2011: 246

\section{RESULTS AND DISCUSSION}

Researchers give questionnaires to subjects to find the latest facts in quantitative undisciplined problems. Questions asked relating to daily life such as Entering class on 
time, orderly traffic, not chatting in class, littering, time management, and about other daily life activities. Use positive questions. The results of the distribution of the questionnaire found the fact that undisciplined is still a student habit. The overall data for each faculty is within \pm 2 or the same as "often". This shows students have not internalized and have not implemented attitudes and disciplinary attitudes in everyday life.

The accumulation of answers is in the number 2 or equivalent to the meaning of the word "often" meaning that the results are often disciplined students in being not yet a habit. These results are better than the meaning of the word "rarely". But the attitude of "often disciplined" is still categorized as undisciplined because discipline should be "always". Of all the questions asked in important parts such as getting into college on time, orderly in traffic, the majority of students answered rarely even answering never. The results will be grouped into two groups. Group of the Faculty of Health and the Faculty of non-Health.

The three faculties of health are at an average of 1.8. The Faculty of Nursing and Midwifery (FKK) stands at 1.87, the Faculty of Medical (FK) is at 1.79, and the Faculty of Health (F. Kes) is 1.77. If converted in the meaning of the word the same as "often" the meaning belongs to the category of undisciplined. Despite the number is better than no health.

The three non-health faculties are on average 2. The Faculty of Business Economics (FEB) is in the rank of 2.13, the Teacher Training and Education Faculty (FKIP) is in the rank of 2.11, and the Engineering Faculty (FT) is in the 2.25. If converted in the meaning of the word the same as "often" including undisciplined categories. This figure is slightly worse than that of the health faculty. Then pay attention to the faculties of each faculty below.

Figure 2

Diagram of the results of the survey using a questionnaire

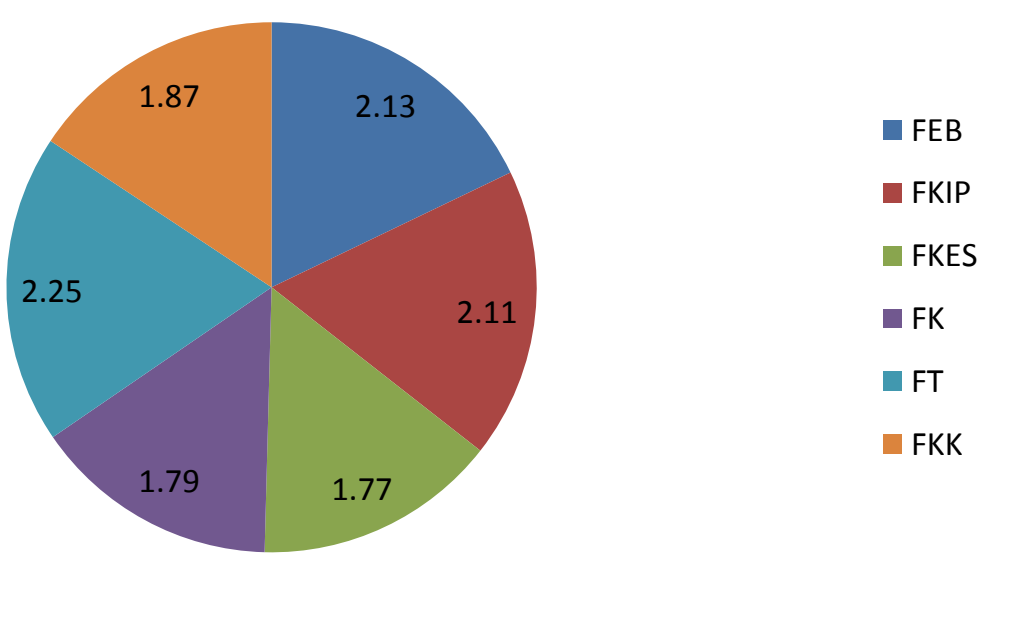


The official documents analyzed put forward a number of reasons for, or causes of, indiscipline. Amongst them are the pupil's home, the school, and the community where the school is located (Araujo 2005). Researchers then conducted interviews with several students from each faculty to confirm and explore in-depth why they were not disciplined. The interview was conducted in person. Some students from FKIP said that when interviewed "they are often disciplined, but that is still not a habit in their daily lives". Usually, people who are often undisciplined enter class late, littering, and sometimes talking or chatting in class during lectures. According to him, life is not disciplined because of environmental influences. All those interviewed from FKIP students acknowledged their lack of awareness. All also agreed that a disciplined life was important, but that understanding could not awaken their consciousness. As one FKIP student said "Sometimes it is not supported by the environment, for example, lecturers are also not disciplined in class, often late being lazy similar to what was said by(Watson 2005). The school contains indiscipline, and this is transformed into an entity that is referred to as 'the problem'. This problem is getting bigger: there are 'year on year rises', assaults are 'skyrocketing', and this is due to a 'growing minority' of pupils.

Sometimes they underestimate littering if the trash is small, like a pressmen wrap. They realize they are littering but they are also "unconscious", meaning that it has become a habit. Garbage bins are not close and the size of the trash is small so they just ignore it. One FKIP student revealed, "yes, because it is small, it only pre men wrap and Garbage bins so that it is ignored".

Answers from research subjects from FKIP students were almost the same, there were no significant differences. All said that discipline was due to lack of awareness and environmental influences, so that discipline was not a daily habit for students. Low awareness due to the understanding of the importance of discipline and the absence of stimulus from the surrounding environment. Although they say discipline is important, they do not have enough insight into the good impact of living a disciplined life.

Interviews conducted with students of the Faculty of Economics and Business (FEB) are not much different from FKIP students. When asked if they understood that a disciplined life was important, all answered understanding. When asked "but why is it still not disciplined in daily life?" They answered because of the environment. They say "due to environmental influences and lack of awareness:". They also revealed that even lecturers 
are often late for class. Therefore sometimes they do not feel guilty even though they are late for class

FEB students interviewed more often break the rules or habits that should be obeyed. According to him often chatting in class because it's boring. "If the lessons and lecturers are not interesting, I will talk in class". They also do not feel guilty because the environment is also like, "I am used to it like this and do not feel guilty because the environment supports it".

Undisciplined is a habit that is supported by the environment and has lasted a long time. Students carry out their daily activities without regard to the norms of discipline. Be punctual in everything, throwing trash in its place, orderly in traffic, not talking in class when the lecture is explained, and other attitudes.

The results of interviews with health group students found no new facts that differed significantly from non-health students. Almost all the answers are the same as the other students. Discipline has not become a habit of daily life because of the environment and lack of awareness of oneself. One of the female students said "actually because of oneself who hasn't been able to obey all the rules and is still lazy to discipline, she still likes procrastinate".

According to them the family actually reminded and advised but there was no significant influence on being disciplined. "Mothers often advise discipline but still have no effect." Even though they were small from school in kindergarten to elementary school, they were disciplined in accordance with the time set by the family. But the more mature they become, the lazier they become.

This means that the cause of students is not disciplined in daily life because of an environment that is not supportive. As stated(Martina 2012). Habitus is acquired through socialization within families and social groups and ultimately shapes one's 'feel for the game and understanding of one's position-and subsequent actions-within a given 'field', or site of struggle for various resources such as the education system(John B. Thompson, Gino Raymond 1993). An environment that has never been blamed or is accustomed to in many ways is undisciplined so it becomes a habit. Awareness to improve is never there despite understanding that discipline is important. Understanding is only limited to the knowledge that has no meaning other than slogans and/or empty adages.

According to set and achieve goals requires consistent self-discipline. If not disciplined and consistent in daily life the results sought will be sporadic and difficult to 
understand. This means that discipline really determines one's success, so it is not surprising that developed countries start from the very high discipline of their people. Even someone's anxiety about the failure of life, such as: poverty, underdevelopment, lagging, the solution is life discipline.

Rohn is not excessive because discipline is the key to the success and progress of a nation. Developed Western countries start from the discipline of the nation and obedience to the rules and laws. Discipline for them has become a part of everyday life. They have a high awareness to behave and behave in accordance with existing norms and rules.

Unlike in Indonesia, discipline is not inseparable in everyday people's lives, including students. The habit of breaking, being late in all activities is often found. Though students are the heirs of the nation's civilization that will continue the life cycle of the nationhood.

Based on observations made in the environment of students of the University Nahdlatul Ulama of Surabaya, undisciplined is often found in daily activities, such as: being late to class, chatting in class, littering, and disorderly in traffic. This fact is further strengthened by the results of a survey using a questionnaire whose results confirm that undisciplined habits become daily life for students.

There are two important factors that can be underlined why students tend to be undisciplined. First, all research subjects, students of the health faculties and non-health faculties, say that it is because of the environment. This is relevant to Pierre Bourdieu's habitus theory, objectivism. Undisciplined attitude can be said as an ongoing attitude from time to time. Growing up in an undisciplined environment will have a direct impact on the attitude of undisciplined students, both in the family, school, community and boarding houses.

This was confirmed through interviews with research subjects, RW stated that: "I have been familiar with an undisciplined attitude since childhood". Being accustomed to an undisciplined attitude since childhood, this becomes an ongoing habit when studying in higher education and can also extend to all other aspects of social life in all activities and actions".

Especially when the school at junior high school because they already feel mature and begin to lose parental control so that they are freer to determine their attitudes and actions. The influence of this environment is getting stronger because students do not have the initiative to change their attitude into discipline and in accordance with the ideal order. 
Instead of changing his attitude, students tend to be indifferent and feel innocent with an undisciplined attitude.

The disciplined attitude becomes a habitus that has settled in the daily lives of students. The undisciplined attitude is integrated and interconnected in daily activities, consciously or unconsciously. Settles and ingrains such as has become a habit of life. These habits are referred to by Pierre Bourdieu as habitus. Habitus is a cognitive structure that mediates between individuals and social reality. Individuals use habitus in dealing with social reality. (Takwin 2009)Entering classes late, attending forums late, breaking traffic signs, littering, and all other activities are daily habits(Murphy 2015).

This social space, individuals with their habitus relate to other individuals and various social realities that produce actions according to their realm and capital. The influence of the environment is not only limited to the availability of facilities and infrastructure, such as wanting to dispose of the garbage far or no. But also the presence of other subjects (friends) who live in the same social and also influence the student's undisciplined attitude.

Undisciplined attitude is influenced by the role of the family who then begins to "let" when children reach adulthood, besides the apathy of the government. As said by LES "when stepping on junior high school parents began to reduce reprimand and control because it might have been considered large, even though the environment (friends) of school greatly influenced me in attitude".

His teacher when he was in senior high school and lecturers at university was no exception, including the environment that influenced undisciplined students. The undisciplined teacher or lecturer, who enters the class late and at will, so the student's undisciplined attitude is legitimized. Lecturers are considered role models and people who have broad insight and knowledge. In line with what was said by FKIP "SM" Senior High School students "sometimes I get annoyed when I get excited when I enter the class but the lecturer is late so I sometimes too late and don't feel guilty".

This dependency phase explains that the cognitive structure and self-concept of students are still unstable in the analysis and synthesis of social phenomenon fluctuations in their environment. Therefore the tendency to imitate someone who is admired (teacher and lecturer) is very dominant. They feel very happy because it turns out lecturers are also often late so they do not feel guilty. 
The second factor that makes students undisciplined is the lack of self-awareness to live discipline and ideal. This means that undisciplined attitudes other than influenced by the environment (objectivism) also come from within individuals or Bourdieu in his habitus said in terms of subjectivism. Self-awareness is a central concept in several divergent approaches to behavior and life. In psychoanalysis, increased awareness of the self is both a tool and a goal (Allan Fenigstein, Michael F. Scheier 1975). (Akrivou 2006) said self-awareness is emotional intelligence and people who have this ability means they can recognize their emotions. Control theory all define self-awareness in terms of knowledge about the self. For example, private self-consciousness represents a disposition to be highly aware of internal states.

However, this form of awareness is defined by its focus rather than by its quality. Thus, high private self-consciousness may reflect a preoccupation with internal states or an open receptivity to them (Ryan 2003). In all matters relating to human good and bad attitudes there is always awareness in them. The importance of human resources themselves to the organization lies in human self-awareness to react positively to work goals or activities that lead to organizational achievement. Awareness can grow because of an understanding and insight about a thing. Conversely, people who do not have the awareness to behave well could be because they do not have enough knowledge and insight about a thing.

Bourdieu uses the term habitus to describe the unconscious aspects or, more specifically, the internalization of societal structures(McLaughlin 2015). The low unconscious or awareness that exists in Unusa students because they do not have enough broad insight into the importance of discipline. This can be true for all people who are undisciplined. Based on an interview with one of the students, SM said "I understand that discipline is important, but yes just understand that discipline is something good. This means that students do not have enough insight into the discipline of having a major impact on life. Students do not have imagination about the future that life in the future is very dependent on the present life.

The low awareness has implications for laziness. According to NL FEB students, "I am lazy to be disciplined, such as getting in on time, throwing trash in its place when it's far away sometimes I throw it carelessly". This can happen because students also do not really understand that their attitude is bad for the future. Not bad for him but for the next life. 
Environment and awareness have a very significant role in making students disciplined(Young 2014). The role of family, teacher-lecturer, friends, boarding-lodging, campus and all matters related to student life. Awareness for disciplines such as: orderly, on time, throwing trash in its place, which is very low in students of awareness can be built because of the insight. This insight will build imagination about the future and the lives of future generations.

Changing the attitude of students who were previously undisciplined to disciplinary attitude is not easy, because undisciplined has become a habit (habitus ) of student life in almost all aspects. Here habitus is operating as a defense mechanism (Reay 2015). Researchers will try to formulate based on the reasons why Unusa students are not disciplined. This formulation can be used as a reference for all who want a disciplined life as a solution to the undisciplined attitude that is often found every day. This formulation is more long-term and basic rather than temporary because undisciplined is an overall complex problem and has become a habit in the wider community.

The first is building a disciplined environment from an early age, starting with family, friends, schools, and government institutions to enforce rules. The environment is very big impact on students from an early age where he grew up, especially family. If the family has applied discipline seriously and will continuously become habituation, or habitus. Then the school environment, especially teachers and if in college lecturers. Because this entity is a role model in attitude(Lizardo 2004).

Students tend to feel innocent and relaxed when their undisciplined habits are also carried out by lecturers. As stated by NL "sometimes I get annoyed because I tried to enter class on time but the lecturer was late". This makes NL in the end no longer trying to be on time or can be said to be relaxed.

Secondly building self-awareness, self-awareness can be broadly defined as the extent to which people are consciously aware of their internal circumstances and their interactions or relationships with others(Campbell 1999). This awareness is usually formed because of an individual's broad understanding or insight on the importance of discipline. Discipline has a very important influence on one's success because through disciplined life someone will manage and manage his life consistently and sincerely.

\section{CONCLUSION}


Undisciplined is a continuous attitude from time to time without stopping. Get hooked in student life without realizing that they are breaking the ideal order. They are also "not aware" that their attitude impacts the future and future generations. Unconsciousness because it is not disciplined has become a habit in everyday life. This attitude has become habitus according to Pierre Bourdieu's theory. Habitus is a cognitive structure that mediates between individuals and social reality. Individuals use habitus in dealing with social reality.

Undisciplined habits are formed due to the influence of the environment, family, friends, and campus. Students said that the undisciplined attitude had a disposition from the environment. This means that the environment legitimizes undisciplined attitudes such as lecturers are also undisciplined, namely being late to class, friends are the same, family doesn't pay attention to their habits. Students also say because of oneself that is there is no awareness of the discipline. The low awareness makes them lazy to discipline which is in accordance with the ideal order.

Awareness is very much influenced by insights about something. Students who have no awareness because of their insights are not enough to explain that discipline is important and fundamental in life. Discipline benchmarks of success and progress of the nation. Imagination about the ideal life and about the future and future generations does not exist in undisciplined students. These limitations are difficult to change students into discipline. So the solution is to familiarize discipline early on from the family and the environment. Then build awareness with broad insights about the discipline and civilization of a nation.

Recommendation in this reseach, if you want to change the problem of undisciplined fundamentally and long-term, then what needs to be done must be fundamental, namely the habituation of disciplined life from an early age (Catharine $\mathrm{H}$. Rankin, et al 2009). In addition, it builds awareness by providing broad insights into discipline and civilization. Families, especially lecturers who have an important role in building awareness. Broad insight can change one's mindset. For future researchers who will research about undisciplined, it is suggested to focus on research on how to build awareness of disciplinary life because this research is still weak in this regardn.

Parents should avoid the hands-off mindset on matters concerning the discipline of their children at school, at home and when engaging in other activities outside the home and school environment. Both the teachers and parents have a critical duty to ensure that children grow up into responsible members of society (Mokaya J. Omote 2015). 


\section{REFERENCES}

Akrivou, Richard E. Boyatzi. and Kleio. 2006. "The Ideal Self as the Driver of Intentional Change." Journal of Management Development 25(07):624-64.

Allan Fenigstein, Michael F. Scheier, and Arnold H. Buss. 1975. "Public and Private SelfConsciousness: Assessment and Theory." Journal of Consulting and Clinical Psychology 43(04):522-27.

Campbell, Paul D. Trapnell and Jennifer D. 1999. "Private Self-Consciousness and the Five-Factor Model of Personality: Distinguishing Rumination from Reflection." Journal of Personality and Social Psychology 76(02):284-304.

Catharine H. Rankin, Thomas Abrams, Robert J. Barry, Seema Bhatnagar, David Clayton, John Colombo, Gianluca Coppola, Mark A. Geyer, David L. Glanzman, Stephen Marsland, Frances McSweeney, Donald A. Wilson, Chun-Fang Wu, and Richard F. ThompsonCatharine H., and Richard F. Thompson. 2009. "Habituation Revisited: An Updated and Revised Description of the Behavioral Characteristics of Habituation." Journal Neurobiology of Learning and Memory 92(02):135-38.

Gyan, Emmanuel. 2015. "Causes of Indiscipline and Measures of Improving Discipline in Senior Secondary Schools in Ghana: Case Study of a Senior Secondary School in Sunyani." Journal of Education and Practice 06(11):19-26.

Helmi, Avin Fadilla. 1996. “Disiplin Kerja.” Jurnal Buletin Psikologi 04(02):32-41.

John B. Thompson, Gino Raymond, and Matthew Adamson. 1993. "Language and Symbolic Power by Pierre Bourdie.” Journal American Anthropologist 95(01):21314.

Lizardo, Omar. 2004. "The Cognitive Origins of Bourdieu's Habitus." Journal for the Theory of Social Behaviour 34(04):375-401.

Macquarrie, Sarah. 2016. "Everyday Teaching and Outdoor Learning: Developing an Integrated Approach to Support School-Based Provision." International Journal of Primary, Elementary and Early Years Education 46(03):345-61.

Martina, Brian D. Barrett and Camille Anne. 2012. "Towards a Non-Deterministic Reading of Pierre Bourdieu: Habitus and Educational Change in Urban Schools." Journal Policy Futures In Education 10(03):249-62.

McLaughlin, Bernhard Wagner and Kenneth. 2015. "Politicising the Psychology of Social Class: The Relevance of Pierre Bourdieu's Habitus for Psychological Research." Theory And Psychology 25(02):202-21. 
Mokaya J. Omote, Dr. Ruth W. Thinguriand Mosiori E. Moeng. 2015. “A Critical Analysis of Acts of Student Indiscipline and Management Strategies Employed by School Authorities in Public High Schools in Kenya." International Journal of Education and Research 03(12):1-10.

Murphy, Cristina Costa and Mark. 2015. Bourdieu, Habitus and Social Research: The Art of Application. New York: Palgrave Macmillan.

Reay, Diane. 2015. "Habitus and the Psychosocial: Bourdieu with Feelings." Cambridge Journal of Education 45(01):9-23.

Richard, Obeng Mensah. 2007. "Indiscipline in Our Society, The Cause of Our Plight."

Rob Warwick, Janet McCray, and Douglas Board. 2017. "Bourdieu's Habitus and Field: Implications on the Practice and Theory of Critical Action Learning." Action Learning: Research and Practice 14(02):1-16.

Ryan, Kirk Warren Brown and Richard M. 2003. "The Benefits of Being Present: Mindfulness and Its Role in Psychological Well-Being." Journal of Personality and Social Psychology 84(04):822- 848.

Takwin, Bagus. 2009. Proyek Intelektual Pierre Bourdieu: Melacak Asal -Usul Masyarakat, Melampaui Oposisi Biner Dalam Ilmu Sosial. Yogyakarta: Jalasutra.

Watson, C. 2005. "Discourses of 'Indiscipline': A Foucauldian Response."' Emotional and Behavioural Difficulties 10(01):55-65.

Young, G. B. 2014. Awareness in Encyclopedia of The Neurological Sciences. USA: Academic Pers. 